\title{
Tryptase, en biomarkør til støtte for den kliniske diagnosen anafylaksi
}

FRA LABORATORIET

\section{ERIK WILHELM VINNES}

E-post: erik.wilhelm.vinnes@helse-bergen.no Erik Wilhelm Vinnes er lege i spesialisering i medisinsk biokjemi ved Avdeling for medisinsk biokjemi og farmakologi ved Haukeland universitetssjukehus.

Forfatteren har fylt ut ICMJE-skjemaet og oppgir ingen interessekonflikter.

\section{TORUNN OVELAND APELSETH}

Torunn Oveland Apelseth er ph.d., spesialist i immunologi og transfusjonsmedisin og seksjonsoverlege ved Avdeling for immunologi og transfusjonsmedisin ved Haukeland universitetssjukehus.

Forfatteren har fylt ut ICMJE-skjemaet og oppgir ingen interessekonflikter.

\section{TORGEIR STORAAS}

Torgeir Storaas er ph.d., spesialist i øre-nese-halssykdommer, godkjent i kompetanseområdet allergologi, seksjonsoverlege ved Seksjon for klinisk spesialallergologi ved Haukeland universitetssjukehus og leder for Regionalt senter for astma, allergi og annen overfølsomhet (RAAO) i Helse Vest.

Forfatteren har fylt ut ICMJE-skjemaet og oppgir ingen interessekonflikter.

Anafylaksi er en potensielt livstruende, systemisk overfølsomhetsreaksjon som diagnostiseres på grunnlag av karakteristiske symptomer og funn. Alle som har gjennomgått en anafylaktisk reaksjon, bør henvises til allergologisk utredning. Tryptasemåling utført i forbindelse med hendelsen vil være sentral i den påfølgende utredningen.

Anafylaksi forårsakes av mastcelleaktivering med påfølgende frigjøring av potente preformerte mediatorer, deriblant histamin og tryptase. Histamin regnes som den primære effektoren og medvirker til symptomene ved anafylaksi, herunder vasodilatasjon, hypotensjon, bronkokonstriksjon, kløe, urtikaria og angioødem. Den korte halveringstiden på 1-6 minutter gjør imidlertid histamin lite egnet som biomarkør ved en anafylaktisk reaksjon. Tryptase er mer stabil med en halveringstid på 90-120 minutter og derfor godt egnet til å sannsynliggjøre en mastcelleaktivering (figur 1)(1). Måling av tryptase anses som gullstandarden blant biomarkører for å skille mellom anafylaksi og lignende kliniske tilstander (2). Tryptase har i seg selv ingen rolle i den akutte behandlingen, men vil kunne være av stor nytte ved den påfølgende allergologiske utredningen. 


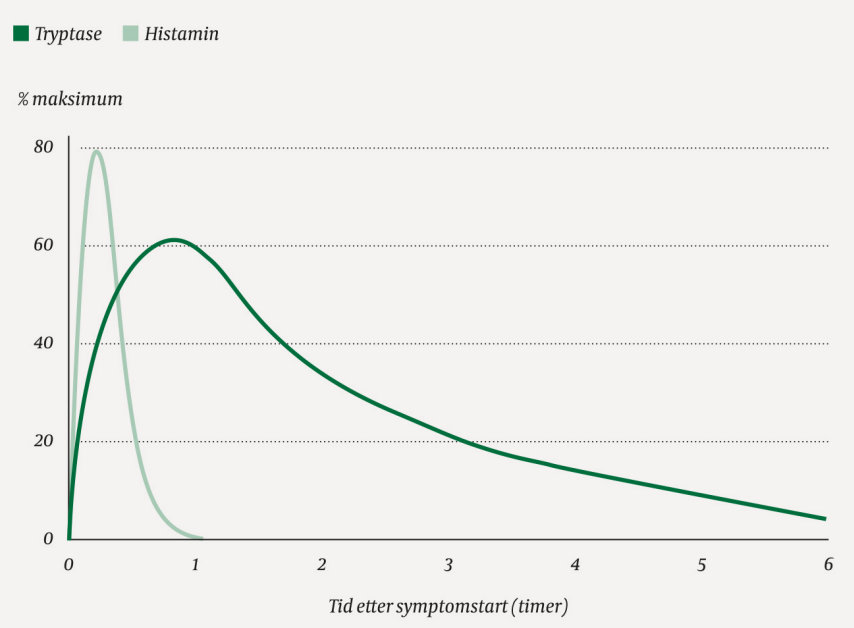

Figur 1 Serumnivå av histamin og tryptase etter mastcelleaktivering. X-aksen viser tid i timer etter symptomstart. Y-aksen viser stigning i prosent. Reprodusert med tillatelse fra Springer Nature (1).

\section{Prøvetakingstidspunkt}

Tryptase må måles både i en akuttprøve (tatt 1-4 timer etter symptomstart) og en basisprøve (tatt tidligst 12 timer etter symptomstart). En praktisk løsning vil være å ta basisprøven i forbindelse med utskrivning etter anbefalt standard observasjonstid på 24 timer (3).

I litteraturen benyttes ofte betegnelser som akutt, straks eller umiddelbar om den første prøven. Et bedre navn hadde kanskje vært 1-4-timersprøven eller førsteprøven, da ord som akutt, straks og umiddelbar kan gi et misvisende inntrykk av at prøven må tas så raskt som overhodet mulig. Dersom prøven tas f.eks. allerede 15-20 minutter etter symptomstart, risikerer man å få en falskt negativ vurdering. Idealtidspunktet for å påvise mastcelleaktivering er trolig rundt 1-2 timer etter symptomstart (4). Et annet poeng er at betegnelsene akutt-, straks- eller umiddelbar prøve potensielt kan bidra til å stjele oppmerksomhet fra den akutte behandlingen. Basisprøven bør ikke utelates, fordi pasienten kan ha systemisk mastocytose, som vanligvis gir vedvarende forhøyede tryptaseverdier. Det anbefales at følgende føres på rekvisisjonen: Tidspunkt for symptomstart, tidspunkt for 1-4-timersprøven og tidspunkt for basisprøven.

\section{Tolkning av tryptase ved anafylaksi}

Tryptasestigningen regnes som signifikant dersom 1-4-timersprøven stiger med mer enn $20 \%+2 \mu g / L$ sammenlignet med pasientens egen «basisverdi» (4).

Eksempel: Det mistenkes perioperativ anafylaksi, og tryptase måles to timer etter symptomstart til 9,5 $\mu \mathrm{g} / \mathrm{L}$. Neste dag er tryptasekonsentrasjonen på 4,1 $\mu \mathrm{g} / \mathrm{L}$. Vi regner da ut at 1-4-timersprøven må overstige $(4,1 \mu \mathrm{g} / \mathrm{L} \cdot 1,2)+2 \mu \mathrm{g} / \mathrm{L}=6,9 \mu \mathrm{g} / \mathrm{L}$ for at tryptasestigningen skal anses som signifikant. Vilkåret er her oppfylt, og stigningen vurderes som signifikant.

Formelen over er blant annet validert i en perioperativ sammenheng med en sensitivitet og spesifisitet på henholdsvis $78 \%$ og $91 \%$. Positiv prediktiv verdi var på $98 \%$, mens negativ prediktiv verdi var lav på $44 \%(2,5)$. Dette betyr at mangel på tryptasestigning $i k k e$ kan utelukke anafylaksi.

\section{Allergologisk utredning}

Alle som har gjennomgått en anafylaktisk episode, bør henvises til allergologisk utredning ved et regionalt senter for astma, allergi og annen overfølsomhet, ved barnepoliklinikk eller hos annen spesialist med allergologisk kompetanse (3). Pasienten skal utredes selv om vedkommende har erfart tilsvarende reaksjoner før den aktuelle episoden, og selv om episoden virket mild eller symptombildet typisk, og årsaken syntes avklart. 
LITTERATUR:

1. Lyons JJ, Schwartz LB. Clinical approach to a patient with elevated serum tryptase: Implications of acute versus basally elevated levels. I: Akin C, red. Mastocytosis, a comprehensive guide. Cham: Springer Link, 2020: 45-6.

2. Beck SC, Wilding T, Buka RJ et al. Biomarkers in human anaphylaxis: A critical appraisal of current evidence and perspectives. Front Immunol 2019; 10: 494. [PubMed][CrossRef]

3. Berstad AK, Storaas T, De Pater GH et al. Norsk veileder i praktisk anafylaksihåndtering. 1. utgave. Oslo: Den norske legeforening, 2014: 19-20.

https://www.legeforeningen.no/contentassets/ede4275911c447979a93f42d1ao4cbfd/norsk-veileder-i-pra ktisk-anafylaksihandtering.pdf Lest 21.9.2020.

4. Schwartz LB. Laboratory tests to support the clinical diagnosis of anaphylaxis. UpToDate.

https://www.uptodate.com/contents/laboratory-tests-to-support-the-clinical-diagnosis-of-anaphylaxis Lest 18.8.2020.

5. Baretto RL, Beck S, Heslegrave J et al. Validation of international consensus equation for acute serum total tryptase in mast cell activation: A perioperative perspective. Allergy 2017; 72: 2031-4.

[PubMed][CrossRef]

Publisert: 26. oktober 2020. Tidsskr Nor Legeforen. DOI: 10.4045/tidsskr.20.0670

Mottatt 25.8.2020, godkjent 21.9.2020.

(C) Tidsskrift for Den norske legeforening 2020. Lastet ned fra tidsskriftet.no 